\title{
FAMILIAL X;Y TRANSLOCATION IN A MALFORMED MALE INFANT AND HIS MOTHER
}

\author{
Shozo OHdo, ${ }^{1}$ Kiyomi Yamada, ${ }^{2}$ Harumichi Madokoro, ${ }^{1}$ \\ Tohru SonOda, ${ }^{1}$ Kenji KaWaguchi, ${ }^{1}$ and Ken-ichi OHBa ${ }^{1}$ \\ ${ }^{1}$ Department of Pediatrics, Miyazaki Medical College, 5,200 Kihara, \\ Kiyotake-cho, Miyazaki 889-16, Japan \\ ${ }^{2}$ Division of Genetics, Clinical Research Institute, National \\ Medical Center, Shinjuku-ku, Tokyo 162, Japan
}

\begin{abstract}
Summary A male infant, the proband, with $46, \mathrm{Y}, \operatorname{der}(\mathrm{X}), \mathrm{t}(\mathrm{X} ; \mathrm{Y})(\mathrm{p} 22.3$; $\mathrm{q} 11.1)$, and his mother with $46, \mathrm{X}, \operatorname{der}(\mathrm{X}), \mathrm{t}(\mathrm{X} ; \mathrm{Y})(\mathrm{p} 22.3 ; \mathrm{q} 11.1)$ are presented. The proband was involved with a peculiar face, congenital heart disease, dry and scaly skin, and growth and psychomotor retardation. He died on the 111th day after birth. At necropsy a congenital heart disease was found, but there was no other major visceral malformation. The mother of the proband was healthy except for her short stature associated with disproportionately short limbs. Steroid sulfatase activity in her skin fibroblasts and lymphocytes was only half that of normal females.
\end{abstract}

\section{INTRODUCTION}

Translocation between $\mathrm{X}$ and $\mathrm{Y}$ chromosome is relatively rare. The majority of these translocations are those between $\mathrm{Xp}$ and $\mathrm{Y}$. In cases having these translocations, life prognosis is generally good. In spite of this trend, however, the proband was involved with a marked growth and psychomotor retardation and congenital heart disease, and died on the 111th day after birth. No reports of X;Y translocation patients complicated with congenital heart disease or who died in infancy have been found.

\section{CLINICAL AND CYTOGENETIC FINDINGS}

Case 1

A male infant, the proband, was born on August 26, 1986 after 42 weeks of gestation as the second child to unrelated parents. The mother of the proband 
(Case 2) had had no experience of spontaneous abortion or stillbirth. When the patient was born, the father was 27 , and the mother 23 . Both his father and brother were healthy, and had normal karyotypes.

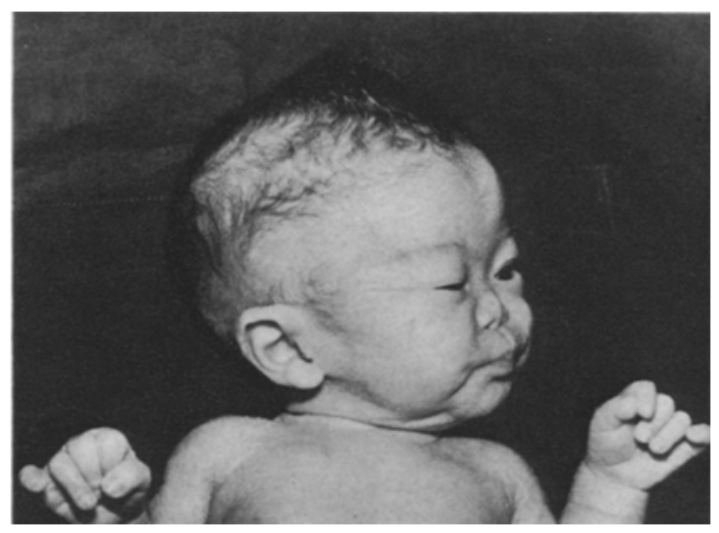

Fig. 1. Facial appearance of the proband at 15 days after birth.

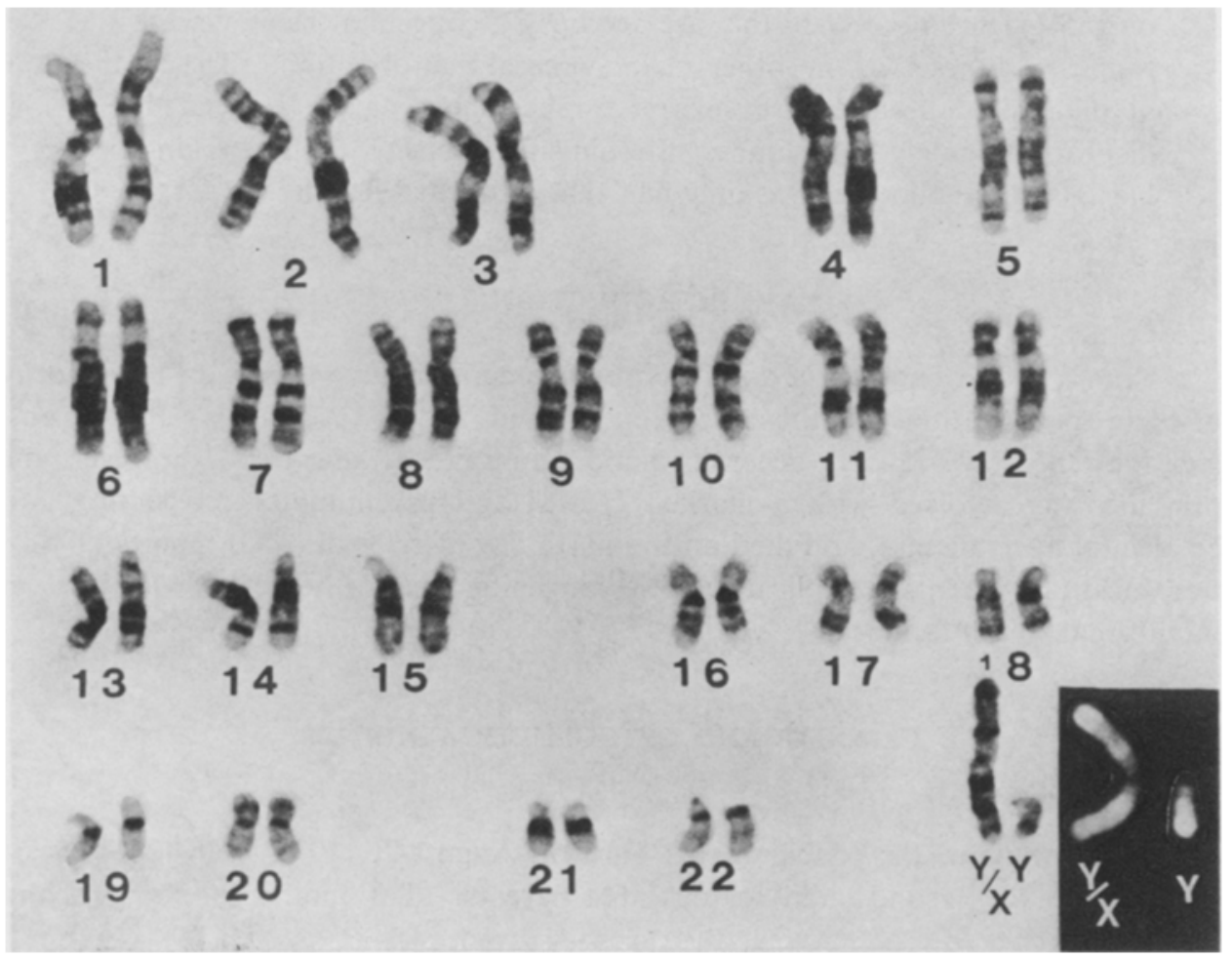

Fig. 2. Complete $\mathrm{G}$ banded karyotype and partial $\mathrm{Q}$ banded karyotype of the proband. 
The birthweight of the proband was $2,230 \mathrm{~g}$, height, $44.5 \mathrm{~cm}$, and head circumference, $31.5 \mathrm{~cm}$. The Apgar score was 9 . After birth nasal feeding was necessary. On September 8, 1986, he was referred to our outpatient clinic due to heart murmurs and peculiar face. At that time, height was $45.3 \mathrm{~cm}(-3.0 \mathrm{SD})$, weight, $2,390 \mathrm{~g}$ $(-2.8 \mathrm{SD})$, and head circumference, $31.8 \mathrm{~cm}(-1.9 \mathrm{SD})$. The anterior fontanel measured 3.5 by $3.5 \mathrm{~cm}$, sagittal suture was splayed at about $1 \mathrm{~cm}$, nasal bridge was depressed, the nose was short and ears were low set (Fig. 1). A grade 3/6 systolic murmur was heard at the upper left sternal border. Lungs and abdomen were unremarkable. The right testis was undescended. Dermatoglyphic analysis revealed bilateral palmar transverse creases, ten digital ulnar loops, and normally placed axial palmar triradii. The skin was dry and scaly. A chest X-ray showed cardiac enlargement (CTR, 0.66). An echocardiogram showed endocardial cushion defect. Result of the routine laboratory test, including $\mathrm{CBC}$, urine analysis, glucose, serum electrolytes, protein, immunoglobulin, $\mathrm{T}_{3}, \mathrm{~T}_{4}$ levels, and TORCH titers were all within normal limits. Blood group typing was not performed. The karyotype on cultured blood lymphocytes revealed $46, \mathrm{Y}, \operatorname{der}(\mathrm{X}), \mathrm{t}(\mathrm{X} ; \mathrm{Y})(\mathrm{p} 22 ; \mathrm{q} 11)$ by quinacrine and Giemsabanding (Fig. 2).

Thereafter, since heart failure persisted, his parents did not wish to continue further examinations. Development during 3 months after birth, as compared with when he was first seen at 13 days, showed no progress.

He died on December 15, 1986. At that time height was $45.5 \mathrm{~cm}(-7.5 \mathrm{SD})$, weight, $2,600 \mathrm{~g}(-5.5 \mathrm{SD})$, and head circumference, $36.0 \mathrm{~cm}(-3.8 \mathrm{SD})$. At necropsy, no major visceral abnormality was found except for incomplete endocardial cushion defect.

\section{Case 2}

The mother of the proband was born on August 30,1963 as the second child to unrelated healthy parents of normal height. Her mother had no experience of

Table 1. Steroid sulfatase activity in skin fibroblasts and peripheral lymphocytes of proband's mother and normal controls.

1. Cultured lymphocytes (EB-stimulated cell-lines)

Normal females $(\mathrm{n}=3)$

$275.6 \sim 320.3$

Normal male $(\mathrm{n}=1)$

132.4

Mother of the proband

120.6

2. Cultured skin fibroblasts

Normal females $(n=6)$

342. $3 \sim 640.6$

Normal males $(n=4)$

173. $3 \sim 212.0$

Mother of the proband

153.6

Unit: $\mathrm{pmol} / \mathrm{mg}$ protein/hr. 


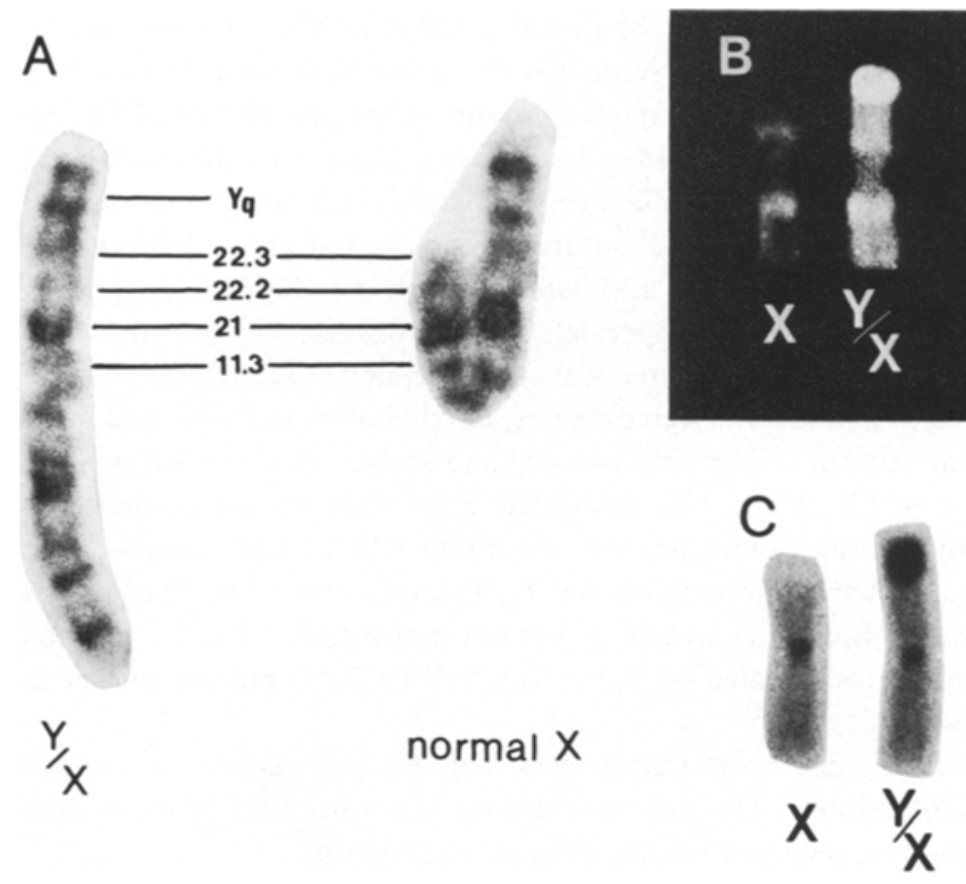

Fig. 3. Normal $\mathrm{X}$ and $\mathrm{X} ; \mathrm{Y}$ translocated chromosome of the proband's mother stained for G-, Q- and C bands. A, G banding; B, Q banding; C, C banding.

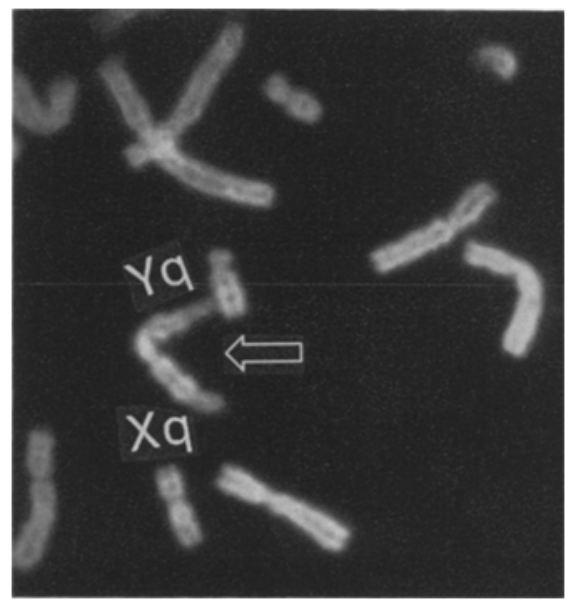

Fig. 4. Late replication of $\mathrm{X} ; \mathrm{Y}$ translocated chromosome. An arrow points to $\mathrm{X} ; \mathrm{Y}$ translocated chromosome. 
spontaneous abortion. Her older sister is also of normal height, and has two healthy children. Her younger sister is also healthy, and of normal height. The mother of the proband is essentially healthy. Menarche occurred at 12 years of age and menstrual periods have been regular.

When she visited our outpatient clinic for investigation of the proband, her height was $138 \mathrm{~cm}$, weight was $41 \mathrm{~kg}$, and arm span was $133 \mathrm{~cm}$. Dermatoglyphics showed normally placed axial palmar triradii with two tented digital arches and eight ulnar loops. On the left palm, a Sydney line was noted, and on the right palm, a transitional four finger crease was observed.

The karyotype on cultured lymphocytes and skin fibroblasts was determined as $46, \mathrm{X}, \operatorname{der}(\mathrm{X}), \mathrm{t}(\mathrm{X} ; \mathrm{Y})(\mathrm{p} 22 ; \mathrm{q} 11)$ from G-, Q- and R-banding findings (Fig. 3).

Steroid sulfatase activity measured by the method of Burstein and Dorfman (1963) is shown in Table 1. Activity in both skin fibroblasts and peripheral lymphocytes was about half that of normal females and in the range of normal males. These results indicated the deletion of $\mathrm{Xp} 22.3$ in the mother, and accordingly her karyotype was $46, \mathrm{X}, \operatorname{der}(\mathrm{X}), \mathrm{t}(\mathrm{X} ; \mathrm{Y})(\mathrm{p} 22.3 ; \mathrm{q} 11.1)$, and the karyotype of the proband was $46, Y$,der(X),t(X;Y)(p22.3; 111.1$)$ mat.

The BUDR-AO method was employed to detect whether the normal or derivative $\mathrm{X}$ was inactivated. Excluding the cells that were difficult to detect, the $\mathrm{X} ; \mathrm{Y}$ translocation chromosome was inactivated in all of 20 examined cells (Fig. 4).

\section{DISCUSSION}

In 1985 Bernstein reviewed 36 cases reported in detail up to that time, which had either $\mathrm{t}(\mathrm{Xp} ; \mathrm{Yq})$ or $\mathrm{t}(\mathrm{Xp} ; \mathrm{Yp})$. To our knowledge, cases subsequently reported to have the same karyotype are 4 by Wegner et al. (1984), 2 by Speevak et al. (1985), probable 7 by Ross et al. (1985), and 1 by Johnston et al. (1987). However, it is not certain whether the familial cases reported by Ross et al. (1985) were the same as those reported formerly by Allderdice et al. (1983). The majority of these cases were familial (Wegner et al., 1984; Speevak et al., 1985; Ross et al., 1985; Allderdice et al., 1983; Van den Berghe et al., 1977; Tiepolo et al., 1977; Pfeiffer, 1980; Åkesson et al., 1980; Boyd et al., 1981; Yamada et al., 1982; Metaxotou et al., 1983). The number of sporadic cases was 10 (Johnston et al., 1987; Van den Berghe et al., 1977; Khudr et al., 1973; Borgaonkar et al., 1974; Bernstein et al., 1978; Hecht et al., 1980; Bernstein et al., 1980; Cohen et al., 1981; Zuffardi et al., 1982).

Clinical symptoms observed in patients having the karyotype of $t(X p ; Y q)$ or $\mathrm{t}(\mathrm{Xp} ; \mathrm{Yp})$ are mainly influenced by the following three cytogenetic conditions: (1) The break-point of the $\mathrm{X}$ chromosome and $\mathrm{Y}$ chromosome in the $\mathrm{X} ; \mathrm{Y}$ translocation chromosome; (2) Whether the patient has a normal $X$ chromosome or a normal $\mathrm{Y}$ chromosome; (3) Whether it is the $\mathrm{X}$ chromosome or the $\mathrm{X}$; $\mathrm{Y}$ translocation chromosome that is inactivated.

Generally speaking, patients having a normal X chromosome are phenotypically 
female, while those who have a normal $Y$ chromosome are phenotypically male. Among those reported in the literature, four phenotypic male patients having a normal $X$ chromosome are included. Although the karyotype of the patient reported by Bernstein et al. (1978) was stated to be 46,X,t(X;Y)(p22;q11), it is possible that it could be reinterpreted to have been Yp (Zuffardi et al., 1982). In other two cases (Bernstein et al., 1980; Zuffardi et al., 1982), Yp was contained in the X;Y translocation chromosome. Since the penetrance of male-determining genes on the $\mathrm{Y}$ chromosome is strong (Ohno, 1976), existence of Yp brings about male manifestation.

Unfortunately, we did not examine steroid sulfatase activity and $\mathrm{Xg}$ blood group in the proband. The gene locus of steroid sulfatase has been assigned to the Xp22.32 band (Human Gene Mapping 8, 1985). Accordingly, various abnormalities noted in the proband must be due to nullisomy from Xp22.3 to pter. Since X-linked ichthyosis is due to steroid sulfatase deficiency, it is probable that ichthyosis would have occurred, had he survived. Steroid sulfatase activity was examined in six familial cases, including our case (Speevak et al., 1985; Ross et al., 1985; Boyd et al., 1981; Metaxotou et al., 1983; Tiepolo et al., 1980) and one sporadic case (Zuffardi et al., 1982). Among these cases, steroid sulfatase activity in female carriers except for those reported by Speevak et al. (1985) showed a value half that of normal females, and was almost zero in male patients.

Many female subjects having the karyotype of $46, \mathrm{X}, \mathrm{t}(\mathrm{Xp} ; \mathrm{Yq})$ are both physically and mentally healthy, except that they have disproportionately short stature. In many of these women, menarche occurred when they were 12 to 15 years old, menstrual periods were regular, and they were fertile. In exceptional cases, some female patients showed several congenital abnormalities other than short stature (Johnston et al., 1987; Pfeiffer, 1980; Hecht et al., 1980; Khudr et al., 1973).

On the other hand, male patients who had the karyotype of $46, \mathrm{Y}, \operatorname{der}(\mathrm{X}), \mathrm{t}(\mathrm{Xp}$; Yq) were all born to mothers who had the karyotype of $46, X, t(X p ; Y q)$. Symptoms commonly noted are short stature, flat nasal root with short nose, hyperterorism, developmental retardation in various degrees, and palmar transverse crease. Other than the above, in cases where steroid sulfatase activity was zero, X-linked ichthyosis was found. Generally all these patients have a good life prognosis. Although intellectual development in most of them was mildly retarded, that of the patient reported by Pfeiffer (1980) was seriously retarded. They were found to have hypogonadism (Yamada et al., 1982). However, it is rather rare that these patients have major malformations. In view of the seriousness of the symptoms, we assume that in our case the range of nullisomy of the $\mathrm{Xp} 22$ to pter region is larger than in past cases in the extent not detectable with current cytogenetic techniques.

\section{REFERENCES}

Åkesson, H.O., Hagberg, B., and Wahlström, J. 1980. Y-to-X chromosome translocation observed in two generation. Hum. Genet. 55: 39-42. 
Allderdice, P.W., Aveling, J.V., Eales, M.J., McAlpine, P.I., Ross, J.B., and Simms, R.J. 1983. Familial $\mathrm{t}(\mathrm{X} ; \mathrm{Y})(\mathrm{p} 22.3 ; \mathrm{q} 11)$ associated with short stature in 4 male and 5 female carriers, and with X-linked ichthyosis and anhydrosis in 4 male carriers. Am. J. Hum. Genet. 35: 124A (Abstr).

Bernstein, R., Wagner, J., Isdale, J., Nurse, G.T., Lane, A.B., and Jenkins, T. 1978. X-Y translocation in a retarded phenotypic male. J. Med. Genet. 15: 466-474.

Bernstein, R., Pinto, M.R., Almeida, M., Solarsh, S.M., Meck, J., and Jenkins, T. 1980. X;Y translocation in an adolescent mentally normal phenotypic male with features of hypogonadism. J. Med. Genet. 17: 437-443.

Bernstein, R. 1985. $\mathrm{X} ; \mathrm{Y}$ chromosome translocations and their manifestations. In The Y Chromosome. Part B: Clinical Aspect of Y Chromosome Abnormalities, Sandberg, A.A., ed., Alan R Liss, Inc., New York, pp. 171-206.

Borgaonkar, D.S., Sroka, B.M., and Flores, M. 1974. Y-to-X translocation in a girl. Lancet 1: 68-69.

Boyd, E., Ferguson-Smith, M.A., Ferguson-Smith, M.E., Jamieson, M.E., Russell, J.E., Aitken, D.A., Sanger, R., and Tippett, P. 1981. A case of $X ; Y$ translocation which maps the Xg locus to Xp24 $\rightarrow$ pter. J. Med. Genet. 18: 224 (Abstr).

Burstein, S. and Dorfman, R. 1963. Determination of mammalian steroid sulfatase with $7{ }^{3} \mathrm{H}-3$ $\beta$-hydroxyandrost-5-en-17-one sulfatase. J. Biol. Chem. 238: 1656-1660.

Cohen, M.M., Frederick, R.M., Balkin, N.E., and Simpson, S.J. 1981. The identification of Y chromosome translocations following Distamycin A treatment. Clin. Genet. 19: 335-342.

Hecht, T., Cooke, H.J., Cerrillo, M., Meer, B., Reck, G., and Hemeister, H. 1980. A new case of $\mathrm{Y}$ to $\mathrm{X}$ translocation in a female. Hum. Genet. 54: 303-307.

Johnston, K., Schonberg, S., Littman, V., Gregory, T., Gelbert, S., O’Donnell, J., and Cox, D.R. 1987. De novo $\mathrm{X} ; \mathrm{Y}$ translocation associated with imperforate anus and retinal pigmentary abnormalities. Am. J. Hum. Genet. 27: 603-611.

Khudr, G., Benirschke, K., Judd, H.L., and Strauss, J. 1973. Y to X translocation in a woman with reproductive failure: A new rearrangement. J. Am. Med. Assoc. 226: 544-549.

Metaxotou, C., Ikkos, D., Panagiotopoulou, P., Alevizaki, M., Mavrou, A., Tsenghi, C., and Matsaniotis, N. 1983. A familial X/Y translocation in a boy with ichthyosis, hypogonadism and mental retardation. Clin. Genet. 24: 380-383.

Ohno, S. 1976. Major regulatory genes for mammalian sexual development. Cell 7: 315-321.

Pfeiffer, R.A. 1980. Observations in a case of an $\mathrm{X} / \mathrm{Y}$ translocation, $\mathrm{t}(\mathrm{X} ; \mathrm{Y})(\mathrm{p} 22 ; \mathrm{q} 11)$, in a mother and son. Cytogenet. Cell. Genet. 26: 150-157.

Ross, J.B., Allderdice, P.W., Shapiro, L.J., Aveling, J., Eales, B.A., and Simms, D., Jr. 1985. Familial X-linked ichthyosis, steroid sulfatase deficiency, mental retardation, and nullisomy for Xp22.3 $\rightarrow$ pter. Arch. Dermatol. 121: 1524-1528.

Speevak, M., Clifford, B., Cox, D.M., and Hunter, A.G.W. 1985. Deletion at amniocentesis of a maternally inherited X;Y translocation. Clin. Genet. 27: 595-599.

Tiepolo, L., Zuffardi, O., and Rodewald, A. 1977. Nullisomy for the distal portion of Xp in a male child with a X/Y translocation. Hum. Genet. 39: 277-281.

Tiepolo, L., Zuffardi, O., Fraccaro, M., di Natale, D., Gargantini, L., Müller, C.R., and Ropers, H.H. 1980. Assignment by deletion mapping of the steroid sulfatase X-linked ichthyosis locus to Xp22.3. Hum. Genet. 54: 205-206.

Van den Berghe, H., Petit, P., and Fryns, J.P. 1977. Y to X translocation in man. Hum. Genet. 36: 129-141.

Wegner, S., Muneer, R., and Rennert, O. 1984. An X;Y translocation, $t(X ; Y)(p 22 ; q 11)$ in three generations. Am. J. Hum. Genet (Suppl) 36: 117S (Abstr). 
Yamada, K., Nanko, S., Hattori, S., and Isurugi, K. 1982. Cytogenetic studies in a Y-to-X translocation observed in three members of one family, with evidence of infertility in male carriers. Hum. Genet. 60: 85-90.

Zuffardi, O., Maraschio, P., LoCurto, F., Müller, U., Giarola, A., and Perotti, L. 1982. The role of $\mathrm{Yp}$ in sex determination: New evidence from $\mathrm{X} / \mathrm{Y}$ translocations. Am. J. Med. Genet. 12: 175-184. 